\title{
Assessment on the Level of Recycling and Waste Management in Delta State, Nigeria
}

\author{
Nkonyeasua Kingsley Egun \\ Department of Biochemistry, Delta State University Abraka, Nigeria P.O. Box 192, \\ Abraka, Delta State, Nigeria \\ Telephone: +2347032157045, E-mail: kenegun@yahoo.com
}

KEYWORDS Waste Management. Recycling. Assessment. Waste. Delta State

\begin{abstract}
Waste management is the collection, transport, processing, recycling or disposal of waste materials produced by human activity, and is generally undertaken to reduce their effect on health, the environment or aesthetics. This work is aimed at assessing the level of recycling and waste management practices carried out in the State, proffer possible solutions for effective take off and running of recycling programs and creating an awareness on the environmental and economic potentials and benefits in the waste management/ recycling industry which has not been given a proper attention as that given to other industries by the State Government and the Federal Government.
\end{abstract}

\section{INTRODUCTION}

Karibo (2008) stated that the word "Waste" is a highly subjective notion. While some persons see waste as a risk to public health and the environment, some find it as a mere necessary inconvenience and nuisance- necessary because it must be generated as long as man exits in the world to carry out day-to-day activities and a nuisance in that a sight of a huge waste dump, is not only unsightly but generates offensive odour apart from its attendant environmental consequences. From his personal perception, waste is a source of income. He further stated that the growing global awareness on sustainable development as well as poor implementation of relevant environmental laws/regulations and the complete absence of waste management resources/facilities within and around major urban cities in developing countries and Nigeria in particular has promoted waste in bad or negative effects.

Recycling according to Wikipedia (2008) is an act which involves processing used materials into new products in order to prevent waste of potentially useful materials, reduce the consumption of fresh raw materials, reduce energy usage, reduce air pollution (from incineration) and water pollution (from land filling) by reducing the need for "conventional" waste disposal, and lower greenhouse gas emissions as compared to virgin production. Recycling has been a common practice for most of human history, with recorded advocates as far back as
Plato in $400 \mathrm{BC}$. In pre-industrial times, there is evidence of scrap bronze and other metals being collected in Europe and melted down for perpetual reuse and in Britain dust and ash from wood and coal fires was down cycled as a base material in brick making (The Economist 2007).

Common recyclable materials include many kinds of glass, paper, metal, plastic, textiles, electronics, aluminium (e.g., cell phones and computers) and concrete aggregates collected from demolition sites which reduces the need for other rocks to be dug up, and in turn saved trees and habitats. Although similar in effect, the composting or other reuse of biodegradable waste - such as food or garden waste - is not typically considered recycling. Also The Garbage Primer (1993) stated that materials to be recycled are either brought to a collection centre or picked up from the curb side, then sorted, cleaned, and reprocessed into new materials bound for manufacturing.

Recycling is a key component of modern waste management and is the third component of the "Reduce, Reuse, Recycle" waste hierarchy (The Garbage Primer, 1993). In a strict sense, recycling of a material would produce a fresh supply of the same material, for example used office paper to more office paper. However, this is often difficult or too expensive (compared with producing the same product from raw materials or other sources), so "recycling" of many products or materials involves their reuse in producing different materials instead e.g., cardboard from used office paper. Also critics of 
recycling claim that it often wastes more resources than it saves, especially in cases where it is mandated by government (Tierney 1996).

Another form of recycling is the salvage of certain materials from complex products, either due to their intrinsic value (e.g., lead from car batteries, or gold from computer components), or due to their hazardous nature (e.g., removal and reuse of mercury from various items).

The Garbage Primer (1993) stated that in order for a recycling program to work, having a large, stable supply of recyclable material is crucial. Three legislative options have been used to create such a supply: mandatory recycling collection, container deposit legislation, and refuse bins. Mandatory collection laws set recycling targets for cities to aim at, usually in the form that a certain percentage of a material must be diverted from the city's waste stream by a target date. The city is then responsible for working to meet this target. Container deposit legislation involves offering a refund for the return of certain containers, typically glass, plastic, and metal. When a product in such a container is purchased, a small surcharge is added to the price. This surcharge can be reclaimed by the consumer if the container is returned to a collection point. A third method of increase supply of recycled is to ban the disposal of certain materials as waste, often including used oil, old batteries, tires and garden waste. The aim of this method is to create a viable economy for proper disposal of banned products, of which care must be taken that enough of these recycling services exist, or such bans will lead to increased illegal dumping. Also legislation has been used to increase and maintain a demand for recycled materials. Four methods of such legislation exist: minimum recycled content mandates, utilisation rates, procurement policies, recycled product labelling.

Both minimum recycled content mandates and utilisation rates increase demand directly by forcing manufacturers to include recycling in their operations, specify that a certain percentage of a new product must consist of recycled material. Utilisation rates are a more flexible option: industries are permitted to meet the recycling targets at any point of their operation or even contract recycling out in exchange for trade able credits.

These programs have been very successful, often resulting in an $80 \%$ recycling rate. Despite such good results, the shift in collection costs from local government to industry and consumers has created strong opposition to the creation of such programs in some areas. Also opponents of the minimum recycled content and utilisation rate mandates claim that they rob the industry of necessary flexibility (The Garbage Primer 1993).

Waste management is the collection, transport, processing, recycling or disposal of waste materials. The term usually relates to materials produced by human activity, and is generally undertaken to reduce their effect on health, the environment or aesthetics. Waste management is also carried out to recover resources from it. Waste management can involve solid, liquid, gaseous or radioactive substances, with different methods and fields of expertise for each. Waste management practices differ for developed and developing nations, for urban and rural areas, and for residential and industrial, producers. Management for non-hazardous residential and institutional waste in metropolitan areas is usually the responsibility of local government authorities, while management for non-hazardous commercial and industrial waste is usually the responsibility of the generator (Wikipedia 2008).

There are a number of concepts about waste management which vary in their usage between countries or regions. Some of the most general, widely-used concepts include:

1. Waste Hierarchy: The waste hierarchy refers to the " $3 \mathrm{Rs"}$ reduce, reuse and recycle, which classify waste management strategies according to their desirability in terms of waste minimization. The waste hierarchy remains the cornerstone of most waste minimization strategies. The aim of the waste hierarchy is to extract the maximum practical benefits from products and to generate the minimum amount of waste (Wikipedia 2008).

2. Extended Producer Responsibility (EPR): This is a strategy designed to promote the integration of environmental costs associated with products throughout their life cycles into the market price of the products (Organisation for Economic Co-operation and Development 1999).Extended producer responsibility imposes accountability over the entire life cycle of products and packaging introduced on the market. This means that firms, which manufacture, import and/or sell products and packaging, are required to be financially or physically responsible for such products after their useful life. They 
must either take back spent products and manage them through reuse, recycling or in energy production, or delegate this responsibility to a third party, a so-called Producer Responsibility Organization (PRO), which is paid by the producer for spent-product management. In this way, EPR shifts responsibility for waste from government to private industry, obliging producers, importers and/or sellers to internalise waste management costs in their product prices (Hanisch 2000). A life-cycle perspective is also taken in Extended Producer Responsibility (EPR) frameworks: "Producers of products should bear a significant degree of responsibility (physical and/or financial) not only for the environmental impacts of their products downstream from the treatment and disposal of their product, but also for their upstream activities inherent in the selection of materials and in the design of products" (Organisation for Economic Co-operation and Development 2001). "The major impetus for EPR came from northern European countries in the late 1980s and early 1990s, as they were facing severe landfill shortages. EPR is generally applied to post-consumer wastes which place increasing physical and financial demands on municipal waste management" (Environment Protection Authority New South Wales 2003).

3. Polluter Pays Principle: In environmental law, the polluter pays principle is the principle that the party responsible for producing pollution should also be responsible for paying for the damage done to the natural environment. With respect to waste management, this generally refers to the requirement for a waste generator to pay for appropriate disposal of the waste. Polluter pays is also known as extended polluter responsibility (EPR). This is a concept that was probably first described by the Swedish government in 1975. EPR seeks to shift the responsibility dealing with waste from governments (and thus, taxpayers and society at large) to the entities producing it. In effect, it internalises the cost of waste disposal into the cost of the product, theoretically meaning that the producers will improve the waste profile of their products, thus decreasing waste and increasing possibilities for reuse and recycling (Wikepedia 2008). Organisation for Economic Cooperation and Development defines extended polluter responsibility as:

A concept where manufacturers and importers of products should bear a significant degree of responsibility for the environmental impacts of their products throughout the product life-cycle, including upstream impacts inherent in the selection of materials for the products, impacts from manufacturers' production process itself, and downstream impacts from the use and disposal of the products. Producers accept their responsibility when designing their products to minimise life-cycle environmental impacts, and when accepting legal, physical or socio-economic responsibility for environmental impacts that cannot be eliminated by design (Organisation for Economic Co-operation and Development 2001)

4. Zero Waste: This is a philosophy that aims to guide people in the redesign of their resourceuse system with the aim of reducing waste to zero. Put simply, zero waste is an idea to extend the current ideas of recycling to form a circular system where as much waste as possible is reused, similar to the way it is in nature (Wikepedia 2008). Zero waste requires that we maximize our existing recycling and reuse efforts, while ensuring that products are designed for the environment and having the potential to be repaired, reused, or recycled ("What is Zero Waste? 2004). The zero-waste strategy is to turn the outputs from every resource-use into the input for another use, or in other words outputs become inputs. An example of this might be the cycle of a glass milk bottle. The primary input (or resource) is silica-sand, which is formed into glass and formed into a bottle. The bottle is filled with milk and distributed to the consumer. At this point normal waste methods would see the bottle disposed in a landfill or similar, but with a zerowaste method the bottle can be saddled with a deposit, at the time of sale, which is redeemed to the bearer upon return. The bottle is then washed, refilled, and re-sold. The only material waste is the wash-water, and energy loss has been minimized. Zero Waste is a goal, a process, a way of thinking that profoundly changes our approach to resources and production. Not only is Zero Waste about recycling and diversion from landfills, it also restructures production and distribution systems to prevent waste from being manufactured in the first place. In addition, the materials that are still required in these re-designed, resource-efficient systems will be recycled back into production (Roper 2006: p. 326).

This work is aimed at assessing the level of recycling and waste management practices carried out in Delta State and creating an awareness on 
the environmental and economic potentials in the waste management/ recycling industry which has not been given a proper attention as that given to other sectors by the State and the Federal Government.

\section{OBSERVATIONS/FINDINGS}

Delta State is a State in the Niger-Delta region of Nigeria. It lies roughly between longitude $5^{\circ} .00 \mathrm{C}$ and $6^{\circ} .45 \mathrm{C}$ East and latitude $5^{\circ} .00$ and $6^{\circ}$. 00 North. The state has a total land area of 16,842 sq. km. The Capital City is Asaba while Warri is the biggest commercial city and most populated in the state. Other major towns are Agbor, Ughelli, Oleh, Ozoro, Oghara, Sapele, Koko, Burutu, Okpanam and Ogwashi-ukwu. It has a human geography typically comprising of the Ijaw, Urhobo, Igbo, Isoko, Itsekiri, Ika, Ukwuani, and other minor ethnic groups whose major occupation major mainly in farming, fishing, hunting and oil exploration. The State is been considered as a miniature version of Nigeria due to its multi-ethnicity. It is an oil producing state with a population of 4, 098, 291 comprising of 2, 674, 306 Males and 2, 024, 085 Females (Federal Republic of Nigeria Official Gazette 2007).

The State's major towns and cities accounts for the bulk of waste materials generated in the State. The types of waste found in the these towns and the State in general are those typical of urban settlements devoid of proper waste disposal systems and majority of its dwellers living in areas designated as slums. These waste materials include papers, plant/ vegetable wastes, metal scraps, glass materials/bottles and plastics/ rubber products. Of these waste materials, plastics, rubber and polythene products pose a great challenge to the State in terms of proper disposal as it is the most widely used packaging material and its long degradable lifespan. The method of waste disposal generally practiced in the State is the Landfill method which is visibly seen located in various parts of the State with some towns having up to five landfill sites. Incineration is also carried out not as a form of recycling (down-cycling) but as a way of reducing the volume of waste on the landfill sites.

Recycling level in the State is very minimal. Currently, metal scraps, aluminium and glass materials/ bottles are the only waste materials collected for recycling in the State by the glass and steel company in the State as they are considered economically viable. Waste papers and paper products, clothing materials, drink cans, plastics and rubber products are left to their natural fate or been incinerated at the dumping sites. This can be attributed to the fact that the production of new ones from their basic raw materials which is readily available in the State is cheaper and more cost efficient.

With respect to waste management, an appreciable effort has been made by the State Government with respect to proper collection and disposal with the provision of large waste collection bins/containers at strategic points within the above listed towns and villages, provision of waste collecting trucks whose duty is to transport the waste generated in the metropolis to the landfill sites, publicity in the various forms of media on the need for proper waste disposal, observation of the last Saturday in every month as sanitation day with the aim of keeping the environment clean and the setting up set up an 11-member committee on waste management charged with the responsibility of proffering solutions to proper refuse management in the state by the Delta State House of Assembly, but nothing major/concrete has been done concerning the recycling concept.

\section{RECOMMENDATIONS}

Firstly, given the multi-dimension of waste, the establishment of recycling companies/ factories aimed at recycling the various types of waste materials (biodegradable and nonbiodegradable) directly by Government or through its environmental agencies or indirectly through partnership with the private sector in the major towns of the state will go a long way in taking care of the recyclable waste materials produced in these towns and their surrounding settlements. This will also lead to the creation of jobs for various levels of manpower (skilled and unskilled) ranging from factory plant operator to waste collector for the increasing population of unemployed youths.

Secondly, the Delta State Government through its State Executive Council and its legislative arm of Government (the Delta State House of Assembly) should enact laws to oversee the success of these recycling companies. The Garbage Primer (1993) stated that in order for a recycling program to work, having a large, stable supply of recyclable material is crucial. Three 
legislative options have been used to create such a supply: mandatory recycling collection, container deposit legislation, and refuse bans. Mandatory collection laws set recycling targets for cities to aim for, usually in the form that a certain percentage of a material must be diverted from the city's waste stream by a target date. The city is then responsible for working to meet this target. Container deposit legislation involves offering a refund for the return of certain containers, typically glass, plastic, and metal. When a product in such a container is purchased, a small surcharge is added to the price. This surcharge can be reclaimed by the consumer if the container is returned to a collection point. A third method of increase supply of recyclates is to ban the disposal of certain materials as waste, often including used oil, old batteries, tyres and garden waste. The aim of this method is to create a viable economy for proper disposal of banned products, of which care must be taken that enough of these recycling services exist, or such bans will lead to increased illegal dumping. Also legislation has been used to increase and maintain a demand for recycled materials. Four methods of such legislation exist: minimum recycled content mandates, utilisation rates, procurement policies, recycled product labelling.

Both minimum recycled content mandates and utilisation rates increase demand directly by forcing manufacturers to include recycling in their operations, specify that a certain percentage of a new product must consist of recycled material. Utilisation rates are a more flexible option: industries are permitted to meet the recycling targets at any point of their operation or even contract recycling out in exchange for tradable credits.

Such laws when are enacted, creates a multiple impact on the economy and environment of the State positively. It will lead to the survival and sustenance of these recycling companies as they are assured of available market for their products either directly or indirectly, and also add to the diversification of the State economy from that which is oil dependent.

It will lead to proper land use, as vast expanse of arable land used for carrying out land fill form of waste disposal and construction of the borrow pits which can be seen in various parts of the State, can be replaced with farm lands thereby contributing to food availability and food security.

Sewage which is usually discharged at the mouth of water bodies, will now be treated, and used in the production of various types of fertilizers, which when made available to farmers to be used in the various types of farming, will lead to an increase in farm yield, quality of farm products and decrease in the overall cost of farm produce.

Environmentally, it will lead to the preservation and conservation of the natural land reserves/ heritage as economic plants/ trees such as rubber and timber trees will not be indiscriminately tapped/ felled for industrial use. Also water bodies within the state will now be safer for the growth of aquatic animals and provision of clean portable water to people living in the rural areas whose access to water is only from these sources.

Also, the quality of air will be improved upon as the various chemical effluents and toxic gases which are daily released into the atmosphere either as a result of decay/ putrefaction of waste materials or by incineration of these waste at the land fill sites will be drastically reduced, thereby checking the green house effect, contributing to the control of global warming in the state own little way and also checking the spread of air and water borne diseases, a common feature of slum residential areas in developing nations of which Nigeria is one of them.

Thirdly, as it is a known fact in developed nations that quality research is the bedrock of technological advancement, the establishment and proper funding of research institutes in one of the State's institutions of higher education by the Delta State Government, with the sole purpose of researching into the various ways of treatment and handling of waste, developing new models of recycling waste products, reengineering of waste material into the production of useful products, will enable the State to be at par with other developed/ developing nations in terms of technology advancement and output.

\section{CONCLUSION}

When these recommendations are considered and put to practice, this will lead to a more viable economy, cleaner, healthier and aesthetic surrounding/settlement, thereby complementing the Delta State Clean and Green initiatives and economic growth in the area of industrialization and diversification of the State's economy. Also the State which is currently seeking active partnership with private investors in order to 
harness her abundant human and material resources should see waste from a different perspective, not as waste to be discarded but as material resources

\section{REFERENCES}

Ackerman F 1997. Why Do We Recycle?: Markets, Values, and Public Policy. Washington: Island Press.

Alan B 2007. The Self-Sufficiency Handbook: A Complete Guide to Greener Living. New York: Skyhorse Publishing Inc.

Castell A, Clift R, Francae C 2004. Extended Producer Responsibility Policy in the European Union: A Horse or a Camel? Journal of Industrial Ecology, 8: 4 - 7 .

Federal Republic of Nigeria Official Gazette 2007. Report of 2006 National Population Census No. 24, vol. 94, 2007, pp. B52 - B53.

Hanisch C 2000. Is Extended Producer Responsibility Effective? Environ Sci. Technol, 34: 170 -175.

Karibo EO 2008. Waste Management and Job Creation in the Niger Delta. A paper presentation at the 2 nd Annual Dare 2 Dream Youth Summit in Effurun, Nigeria August 30, 2008.

Organisation for Economic Co-operation and Development 2001. Extended Producer Responsibility: A Guidance Manual for Governments. Paris,
France. From Organisation for Economic Cooperation and Development fact sheet about EPR:<http://www.oecd.org/document> (Retrieved September 22, 2008).

Roper W 2006. Strategies for building material reuses and recycle. International Journal of Environmental Technology and Management, 6: 313 - 345

The Economist, Weekly, June 7, 2007 "The truth about recycling" < http://www.economist.com> (Retrieved September 28, 2008)

The League of Women Voters 1993. The Garbage Primer. New York: Lyons \& Burford, pp. 35-72.

Tierney J 1996. Recycling Is Garbage. New York Times, Daily, June 30, 1996, P. 3.

Tong X., Lifset R, Lindhqvist T 2004. Extended Producer Responsibility in China: Where is Best Practice? Journal of Industrial Ecology, 8: 6-9.

Wikipedia 2008. Recycling. Website $2008<$ http:// www.wikipedia.org > (Retrieved September 27, 2008).

Winter J 2007. A world without waste-The 'zero waste' movement imagines a future where everything is a renewable resource. The Boston Globe, pp. 1-3. From LexisNexis database: Website 2008 <https:// www.lexisnexis.com> (Retrieved September 22, 2008).

Zero Waste California Fact Sheet 2004. What is Zero Waste California? From Website $2008<$ http:// www.zerowaste.ca. gov/WhatIs.htm> (Retrieved September 29, 2008), 